\title{
APATITE AND SPODIOSITE ${ }^{1}$
}

\section{BY FRANK K. CAMERON AND W. J. MCCAUGHEY}

Apatite is a constituent of all rocks. ${ }^{2}$ Consequently its presence, to some extent, should be expected in every soil, and this expectation has been confirmed by the microscopic examination of a large number of samples of various types from many parts of the United States. ${ }^{3}$ It is slightly soluble and is hydrolyzed by water, the natural apatites yielding an alkaline solution but one also containing phosphoric acid. It has therefore an iniportance in soil investigations. It is a carrier of an essential plant nutrient and it is often a guide to the genesis of a particular soil. In the investigation ${ }^{4}$ of the phosphates of lime which is in progress in this laboratory, apatite is being studied, and in this paper attention is directed to some observations which have been made upon this compound and the related substance, spodiosite.

Apatite has been reported as made artificially in several ways: by the action of phosphorus trichloride on caustic lime, ${ }^{5}$ by passing hydrochloric acid over red hot tricalcium phosphate, ${ }^{\circ}$ by melting tricalcium phosphate in sodium chloride, ${ }^{7}$ and by melting tricalcium or trisodium phosphate in calcium fluoride or a mixture of these salts. ${ }^{8}$ It has also

${ }^{1}$ Published by permission of the Secretary of Agriculture.

${ }^{2}$ Rosenbusch u. Wulfing: Mikrosk. Physiog. Min. u. Gest., 4 Auf. Bd. I, H. 2, IO8 (I905); Emmons: Economic Geology, 3, 6I I (Ig08).

${ }^{3}$ From the literature bearing on this point, the work of Retgers on the dune sands of Holland is especially interesting. See N. Jahrb. für Min., I, I6 (I 895).

4 Bull. No. 4I, Bureau of Soils, U. S. Dept. of Agriculture; Jour. Am. Chem. Soc., 26, 885 (1904); 27, I503, I5I2 (1905); 28, I222 (1906); 32, 869 (I9IO); Jour. Phys. Chem., II, 363 (1907).

${ }^{5}$ Debray: Comptes rendus, 32, 625 (185I); Ann. des Min., (4) I9, $68_{4}$ (185I).

'Debray: Comptes rendus, 59, 42 (I864).

7 Forchhammer: Liebig's Ann., 90, 77 (1854).

8 Manross: Liebig's Ann., 82, 388 (1852); Briegleb: Ibid., 97, 95 (1856); Sainte-Claire Deville et Caron: Comptes rendus, 47, 985 (1 858 ). 
been reported as present in basic slags. ${ }^{1}$ It has been made in the wet way. ${ }^{2}$

In order to obtain a pure chlorapatite of definite composition, it seemed desirable to prepare it by dissolving tricalcium phosphate in fused calcium chloride. On cooling the melt, and lixiviating with water, a granular crystalline product was obtained. A microscopic examination showed that the product was all one substance, and that it was not apatite. An analysis of the substance was made by $\mathrm{Mr}$. W. H. Waggaman. This analysis, together with determinations of its crystallographic and optical properties, showed it to be a chlor analogue of the mineral spodiosite, ${ }^{8}$ which contains relatively more halogen than does apatite.

The experiment was then tried of melting a natural chlorapatite ${ }^{4}$ in fused calcium chloride, and lixiviating the cooled product. This procedure also yielded only chlorspodiosite 4 .

Several repetitions of the experiment of melting precipitated calcium phosphate in fused chloride gave the spodiosite only, but ultimately a product was obtained which contained also some apatite. If, now, apatite- $\mathrm{Ca}_{3}\left(\mathrm{PO}_{4}\right)_{2}{ }^{1}{ }_{3}{ }_{3} \mathrm{CaCl}_{2}-$ and spodiosite- $\mathrm{Ca}_{3}\left(\mathrm{PO}_{4}\right)_{2} \cdot \mathrm{CaCl}_{2}$-be considered as tricalcium phosphate, crystallizing with definite proportions of calcium chloride, it is apparent that the solid phase which will separate from the liquid calcium chloride at any given temperature is determined by the ratio of lime to phosphoric acid in the liquid phase, and that there is one particular ratio at which both apatite and spodiosite can exist. Consequently to ensure the formation of apatite alone, it should be sufficient to increase the ratio of phosphoric acid to lime, which obtained in the experiments just cited. This might

${ }^{1}$ Stead and Risdale: Jour. Chem. Soc., 5I, 60I (I887); Hutchings: Nature, 36,460 (1887).

${ }^{2}$ Weinschenk: Zeit. für Kryst., I7, 489 (1890).

${ }^{3}$ Fiborg: G. För Förh., I, 84 (1872); Sjögren: Ibid., 7, 666 (1884-'85); Nordenskiold: Ibid., I5, 460 (1893).

${ }^{4}$ An analysis of this mineral showed 5.55 percent chlorine. 
have been done by passing dry hydrochloric acid through the melt, which would have been to all intents and purposes repeating the experiment of Debray cited above. Actually, it was accomplished by adding an excess of dicalcium phosphate to molten calcium chloride, cooling, and washing out the calcium chloride, when a granular crystalline product was obtained which proved to be entirely apatite. When a basic phosphate of lime was used, instead of the dicalcium phosphate, the resulting product was entirely spodiosite.

These results indicate that apatite is formed in nature under the condition that there is present some fairly strong acid in the molten magma or mother liquor. This conclusion appears to be supported by mineralogical and petrographical observations on igneous rocks where the apatite is often present as inclusions in other minerals, indicating that apatite was one of the first if not the first mineral to separate from the magma, before the excess of free acids had yet escaped. ${ }^{1}$ The formation of both chlor- and fluorapatite in the wet way has been accomplished in this laboratory, and will be discussed later.

Several procedures were attempted for the preparation of pure fluor-apatite. It was finally made by dissolving calcium fluoride in fused disodium phosphate, and lixiviating the cooled melt. The resulting product was a mixture of apatite and fluorite crystals. The optical properties of the fluorapatite were determined but no chemical analysis was attempted because of the difficulty of separating the apatite from the fluorite, and no reasonable doubt can exist as to the composition of the apatite.

The artificial chlorapatite consists of long and short hexagonal prisms with bipyramidal terminations, Fig. I. Occasionally twins are observed. The crystals vary in size from a diameter of about $0.2 \mathrm{~mm}$ to extremely small ones no larger than the microscopic inclusions of apatite in rocks and

'In connection with this, see a recent statement by Kemp: Economic Geology, I, 230 (rgo6). 
soil grains. The specific gravity of the pure chlorapatite is 3.oro. According to Gladstone's law, this would indicate an index of refraction of $\mathrm{I} .65 \mathrm{O}$. The observed index of refraction for the ordinary ray in sodium light is $\mathrm{I} .666$. This value is considerably higher than values of natural apatites as given by Rosenbusch. An examination of the analyses in Dana's system of mineralogy shows that nearly all the apatites reported are the fluor variety except those from Norway. Unfortunately the optical data of the latter have not been published. A chlor-apatite from an unknown locality has been analyzed by Mr. Waggaman, who reports 5.55 percent chlorine. The index of refraction of the ordinary ray for this chlor-apatite is 1.655 . It is therefore to be expected that the

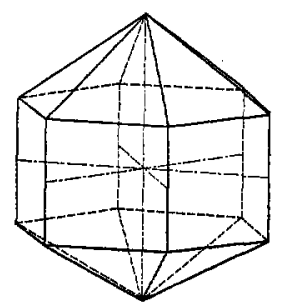

Fig. I

pure chlor-apatite containing 6.8 percent chlorine would have a still higher index, and this is confirmed by the observations just cited. Again according to Dana the interfacial angle ooor $\wedge$ IO $\bar{I} I$ in apatite is something over $40^{\circ}$ but diminishes slightly as the ratio of chlorine to fluorine increases. This angle has been measured for the pure chlor-apatite just described, and the average of fairly concordant measurements on five individual crystals was found to be $39.4^{\circ}$. The birefringence for artificial chlor-apatite is probably less than 0.002 and that of the natural chlor-apatite is likewise low.

An analysis of the artificial chlor-apatite, by Mr. Waggaman, gave the following results: 


\begin{tabular}{c|c|c}
\hline & Chlor-apatite $: \mathrm{Ca}_{8}\left(\mathrm{PO}_{4}\right)_{4} \cdot 1 / 3 \mathrm{CaCl}_{2}$ \\
\hline $\mathrm{Ca}$ & Found & Calculated \\
\hline $\mathrm{P}$ & 38.0 & 38.5 \\
$\mathrm{Cl}$ & $\mathrm{I} . \mathrm{I}$ & 17.9 \\
& 6.8 & 6.8
\end{tabular}

The artificial fluor-apatite crystallized in elongated hexagonal prisms, terminated, however, by the basal pinacoid. This is a point of particular interest, because the artificial chlor-apatite invariably crystallized with well developed pyramidal faces, whereas the natural apatites occurring in rocks and soils, like the artificial fluor-apatite, do not show the pyramidal faces, but are terminated generally by the basal pinacoid. Moreover, the artificial fluor-apatite shows sometimes the further peculiarity of phantom crystals with a reentrant pyramid as indicated in Fig. 2. The index

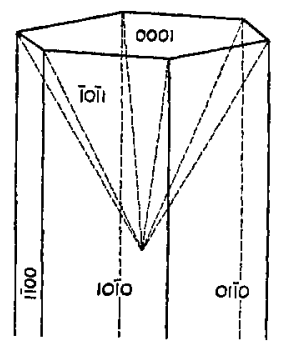

Fig. 2

of refraction of the ordinary ray for sodium light is r.635 which agrees well with the published figures for natural apatite. The birefringence of the artificial fluor-apatite is about the same as that found in ordinary specimens of natural apatites.

Other apatites have been reported in which the chlorine or fluorine is replaced by bromine, iodine or hydroxide. Unfortunately little or nothing is known of the optical properties of these minerals, and not much more perhaps of the apatites 
in which calcium is replaced by barium or other bases. ${ }^{1}$ One compound however is of special interest here, which is apparently an apatite containing calcium silicate instead of calcium fluorite, namely, $\mathrm{Ca}_{3}\left(\mathrm{PO}_{4}\right)_{2} \cdot{ }_{1}{ }_{3} \mathrm{Ca}_{3} \mathrm{SiO}_{5}$, described by Vogt $^{2}$ as belonging to the hexagonal system. This is apparently the hexagonal mineral found in Thomas slag and described by Miers ${ }^{3}$ who observed prisms, terminated by basal pinacoids, and sometimes showing forms, with a reentrant pyramid, like the fluor-apatites described above. Miers, however, ascribed these reentrant pyramids to cleavage. Examination in this laboratory of the yellowish hexagonal needles occurring in Thomas slag show a great similarity to naturally occurring apatites. The index of refraction for the ordinary ray is 1.630 . The birefringence is weak $(\omega-\varepsilon \overline{\overline{<}} 0.004)$ and negative.

The artificial chlor-spodiosite is generally in flat rhombic tables, of the orthorhombic system as shown in Fig. 3. The

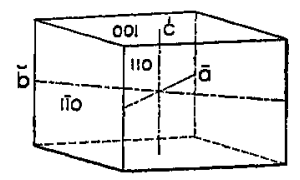

Fig. 3

crystals, $0.02-0.05 \mathrm{~mm}$ in diameter, consist of short unit prisms (I IO) terminated with a prominent basal pinacoid (ooI) so that they appear flattened parallel to the vertical axis. Occasionally some of the forms show a development of the brachy pinacoid (oro). The mineral possesses a very good basal cleavage. The specific gravity at $23^{\circ}$ (uncorrected)

is 3.04I. The prism angle $1 \mathrm{IO}: \mathrm{I} \overline{\mathrm{I} O}$ is $82^{\circ}$. The acute bisectrix $(=\mathfrak{x})$ is coincident with the direction of the crystal-

\footnotetext{
${ }^{1}$ For references to the literature, see Groth: Chemische Krystallographie, Zweiter Teil, 8I8 (rgo8).

${ }^{2}$ Die Silikatschmelzlösungen, I, 5 ( $19 \circ 3$ ).

${ }^{s}$ See articles by Stead and Risdale: Jour. Chem. Soc., 51, 60I (1887).
} 
lographic axis (c). The indices of refraction determined by oil immersion methods for sodium light are

$$
\begin{aligned}
& \alpha=1.649 \\
& \beta=1.665 \\
& \gamma=1.670
\end{aligned} \quad \stackrel{c}{c}=\mathfrak{t}
$$

The birefringence is notably high and is positive $\gamma-\alpha=$ $0.02 \mathrm{I}$. The spodiosite found at Nordmark in Sweden occurs in orthorhombic crystals elongated in the direction of crystallographic axis $d$, flattened parallel to $a$, and consequently shows prominently the brachy pinacoids (oro). The unit prism (IIO) and pyramid (III) are next in prominence and traces of the basal pinacoid (OOI), macro pinacoid (IOO) and brachy dome (O2I) are found in some of the crystals. The angle IIO: I $\mathrm{I}$ o is given as $84^{\circ}$, determined with a contact goniometer.

The optical properties of natural spodiosite have not been determined but those of the corresponding magnesium analogue, Wagnerite $\left(\mathrm{Mg}_{3}\left(\mathrm{PO}_{4}\right)_{2} \cdot \mathrm{MgFl}_{2}\right)$, are well known. The apparent difference in the angle r ro: $\mathbf{1}$ Io $\left(84^{\circ}\right.$ in natural spodiosite and $82^{\circ}$ in artificial chlorspodiosite) may be due to the fact that the crystals of artificial chlorspodiosite were so small that the prism angle had to be determined by rotation of the microscope stage. An error of two degrees due to slight irregularity in the faces of the minute crystals is quite possible. The error may be due to the natural shortcomings of the goniometrical method. This difference is more probably due, however, to a difference in chemical composition in that chlorine replaces fluorine, similar to the difference in angle between basal pinacoid and pyramid for chlor-apatite and fluor-apatite respectively, as pointed out by Dana, ${ }^{1}$ and as shown by the measurements on pure chlor-apatite, the average of which is given above.

Artificial chlor-spodiosite is very slightly soluble in water, and neither it nor the artificial chlor-apatite give a solution alkaline to phenolphthalein, when boiled with water,

${ }^{1}$ Dana: System of Mineralogy, p. 764, 6th edition (1892). 
as do all the natural apatites examined in this laboratory. The spodiosite is much more readily soluble in the presence of mineral acids than is the apatite. Heated almost to dull redness the spodiosite is completely transformed to apatite. Apparently, spodiosite is not commonly found in rocks and slags, because these latter have solidified at temperatures at which spodiosite is not stable over any appreciable range of concentration.

An analysis of the artificial chlor-spodiosite, by $\mathrm{Mr}$. Waggaman, gave the following results:

\begin{tabular}{c|c|c} 
& \multicolumn{2}{|c}{ Chlor-spodiosite $: \mathrm{Ca}_{3}\left(\mathbf{P O}_{4}\right)_{2} \mathrm{CaCl}_{2}}$. \\
\hline & Found & Calculated \\
\hline $\mathrm{Ca}$ & 37.8 & 38.0 \\
$\mathrm{P}$ & 14.7 & 14.7 \\
$\mathrm{Cl}$ & 16.36 & 16.7
\end{tabular}

To summarize the foregoing:

I. Pure chlor-apatite has been prepared. It differs from pure fluor-apatite and the natural apatites in crystal habit, and in certain optical measurements.

2. Pure fluor-apatite has been prepared. It differs from natural apatites mainly in having a tendency to form phantom crystals.

3. Pure chlor-spodiosite has been prepared. It differs from the natural fluor-spodiosite in crystal habit. Optical measurements have been made for pure chlor-spodiosite.

4. The value of certain optical measurements and interfacial angles in apatite and spodiosite respectively are determined by the ratio of chlorine to fluorine which the mineral contains.

5. Either acid conditions in the magma, or fluidity at high temperatures only, induces the formation of apatite.

6. Apparently apatite is one of the first minerals to separate from a molten magma. It is sometimes formed from aqueous solutions. It is present in all rocks and in all soils. 